\title{
MULTIPROXY PALEOENVIRONMENTAL RECONSTRUCTION: THE PIRAEUS COASTAL PLAIN CASE STUDY
}

\author{
Triantaphyllou M.V.' ${ }^{1}$, Pavlopoulos K.P. ${ }^{2,3}$, Kouli K. ${ }^{1}$, Koukousioura O. ${ }^{4}$, \\ Dimiza M.D. ${ }^{1}$, Aidona E. ${ }^{4}$, Syrides G. ${ }^{4}$, Pallikarakis A. ${ }^{6}$, Goiran J.-P. ${ }^{7}$ and \\ Fouache E. ${ }^{2}$ \\ ${ }^{1}$ University of Athens, Faculty of Geology and Geoenvironment, Department of Historical \\ Geology-Paleontology, Panepistimiopolis, 15784 Athens, Greece, mtriant@geol.uoa.gr \\ ${ }^{2}$ Paris-Sorbonne University Abu Dhabi, Department of Geography and Planning \\ ${ }^{3}$ Harokopion University,70 El Venizelou Street, 17671 Athens, Greece \\ ${ }^{4}$ Aristotle University of Thessaloniki, School of Geology, 54124, Thessaloniki, Greece \\ ${ }^{6}$ Agricultural University of Athens, Department of Natural Resources Management \& Agricultural \\ Engineering, Laboratory Mineralogy - Geology, IeraOdos 75, Athens 118 55, Greece \\ ${ }^{7}$ Centre National de la RechercheScientifique (CNRS), UMR 5133-Archéorient, MOM, 7 rue \\ Raulin, 69007 Lyon, France
}

\begin{abstract}
The joint application of benthic foraminifera, pollen and non-pollen palynomorphs (NPPs), molluscs and magnetic susceptibility analyses in Piraeus coastal plain deposits resulted in the detailed study of palaeoenvironmental evolution of the area during almost the last 9000 years and the distinction of five lithostratigraphicalpaleoenvironmental units and subunits. Combined results of our analyses features the occurrence of an inner lagoon (unit Aa) followed by an open lagoon (Unit Ab) depositional environment that was transformed to a shallow marine paleoenvironment with lagoonal features (Unit B) after 7800 BP. Since about 4800 $B P$ a closed oligohaline lagoon (Unit $C$ ) used for grazing, occurred in the area, while after 2800 BP a marshy oligohaline depositional environment (Unit D) and signs of intensive agricultural activities are evidenced. The very good correlation of benthic foraminiferal, palynological, molluscan and magnetic susceptibility data and resulted indices is indicative of the potential of the applied methodologies as a paleoenvironmental tool box.
\end{abstract}

Keywords: benthic foraminifera, pollen, NPPs, molluscs, magnetic susceptibility, Holocene.

\section{Пєрі́ $\eta \psi \eta$}

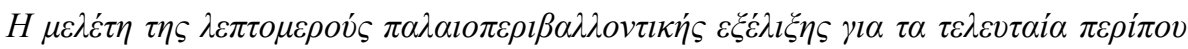

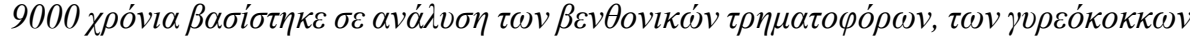

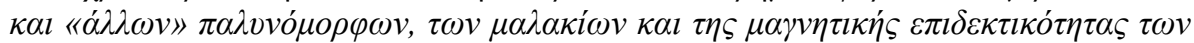

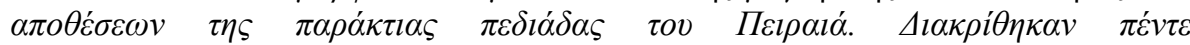

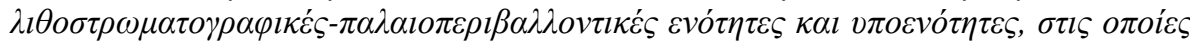




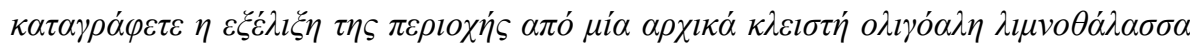

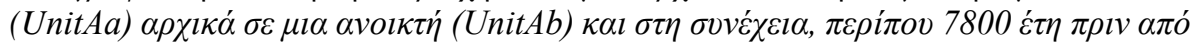

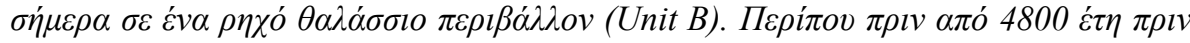

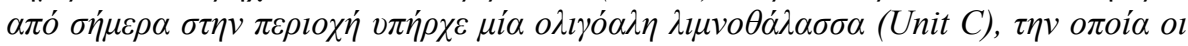

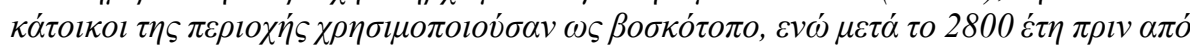

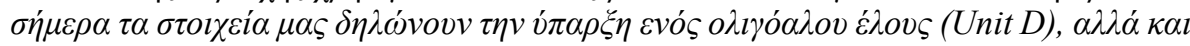

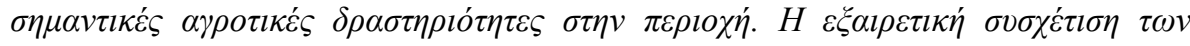

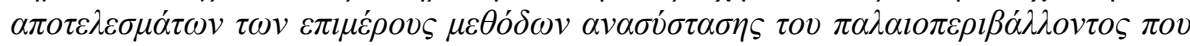

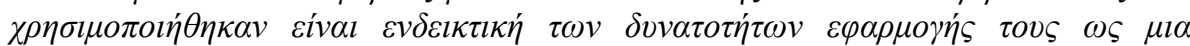

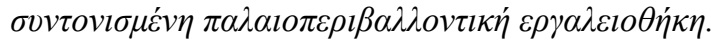

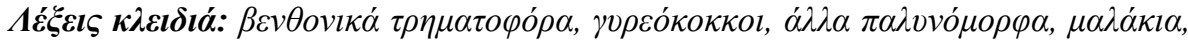

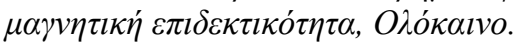

\section{Introduction}

The sedimentary sequences deposited between the hill of Piraeus and the plain of Kephissos (Attiki peninsula, Greece), comprise the Piraeus coastal plain (Figure 1). The main factors that feature in the evolution of the Piraeus coastal landscape have been described as the relative sea level rise in the Holocene due to the reaction to glacio-hydro-isostatic changes, the tectonic stability of the area documented by the relative absence of earthquakes during the last few thousand years, the low tidal range $( \pm 0.25-0.30 \mathrm{~m})$ and the progradation of the deltaic fan of the Kephissos river (Goiran et al. 2011). The palaeoenvironmental interpretation suggested by Goiran et al. (2011), implies that between 6800 and $5400 \mathrm{yr}$ cal. BP, Piraeus was an island in the centre of a shallow marine bay. Until $\sim 3500 \mathrm{yr}$ cal. BP, a wide oligohaline lagoon separated the island of Piraeus from the mainland. This lagoon was filled in periodically by the deltaic fans of the Kephissos and Korydallos rivers. Piraeus became connected to the mainland after $3000 \mathrm{yr}$ cal. BP and before the sixth century BC.

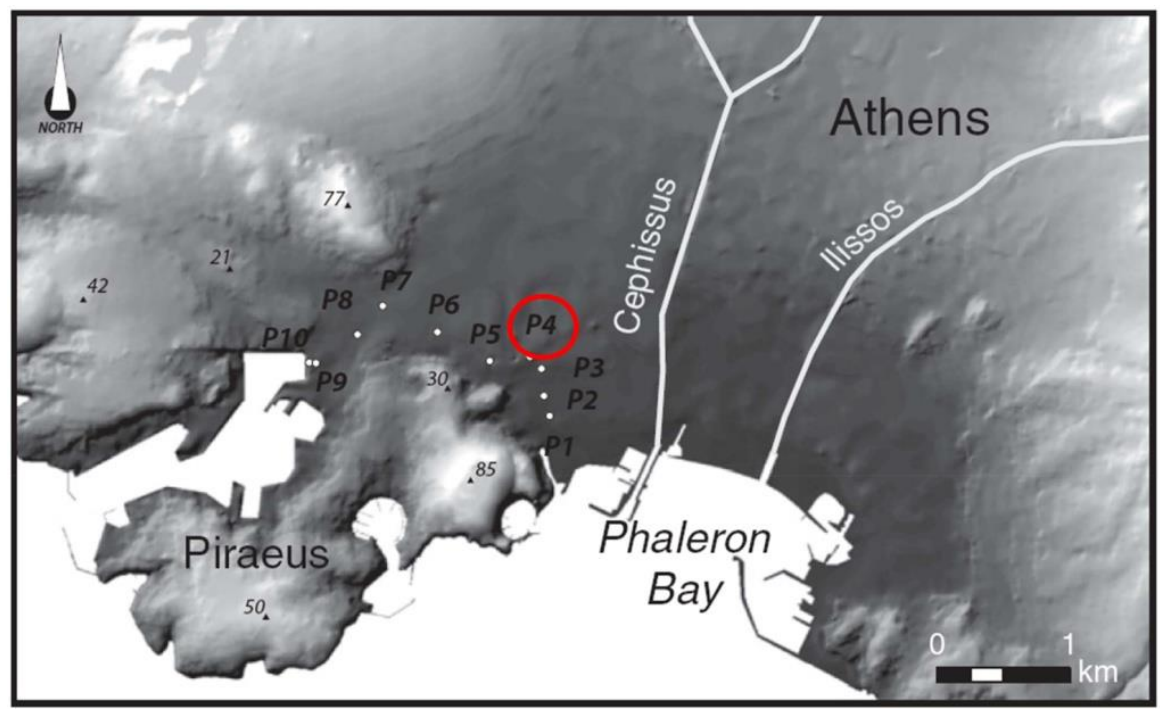

Figure 1 - Location map of borehole P4 in Piraeus coastal plain, Attica (Goiran et al., 2011).

In coastal marine and lagoonal environments where environmental stress is inherently high, benthic foraminifera are the most abundant shelled microorganisms representing one of the most sensitive environmental indicators (Murray, 2007). Changes in benthic faunal abundance, species composition provide evidence of fluctuation in several environmental factors and can therefore be used as an efficient method of determining the ecosystems conditions (e.g., Frontalini and Coccioni, 2008; Koukousioura et al., 2011, 2012). In addition, changes in fossil benthic foraminifera, recorded by the study of coastal zone deposits, are a successful palaeontological tool for recording past sea- 
level changes and reconstructing detailed paleoclimatic and palaeoenvironmental conditions (e.g., Scott and Medioli, 1980; Carboni et al., 2010; Pavlopoulos et al., 2007, 2010; Triantaphyllou et al., 2010; Koukousioura et al., 2012).

Pollen analysis of coastal sediments considers the pollen input deriving from the vegetation of the entire river catchment, mixed together with the "local" component coming from the littoral vegetation (Bellini et al., 2009; Sadori et al., 2010), therefore the palaeovegetational reconstruction, not only relates to the local environment of the site but also to the entire south-eastern Attica basin (e.g., Kouli, 2012). The location of Piraeus coastal plain close to the City of Athens makes it an excellent opportunity of tracing human shaping of the plant landscape during Prehistory and in the Antiquity.

In environmental magnetism, rock and mineral magnetic techniques are used to investigate the formation, transportation, deposition, and post depositional alterations of magnetic minerals under the influences of a wide range of environmental processes. All iron-bearing minerals are sensitive to a range of environmental processes, which makes magnetic measurements extremely useful for detecting signals associated with environmental processes (Liu et al., 2012). In particular, magnetic susceptibility measurements can be used as a rapid, simple and non-destructive proxy to indicate magnetic changes in the sediments corresponding to different depositional environments (Oldfield and Yu, 1994; Verosub and Roberts 1995; Dearing, 2000; Ghilardi et al., 2008; Yang et al., 2008; Wang et al., 2009).

The present study aims to provide further interpretations concerning the paleoenvironmental evolution of the area of Piraeus coastal plain since about 9000 BP, with the combined use of micropaleontological studies of benthic foraminiferal assemblages, palynological and molluscan investigations and magnetic susceptibility of the underlying Late Holocene coastal deposits.

\section{Material and Methods}

Core $\mathrm{P} 4$ has been selected among ten rotational boreholes $(10 \mathrm{~cm}$ in diameter) that were drilled in the Piraeus coastal plain; for core description, samplings and radiocarbon dating framework see Goiran et al. (2011). Core P4 samples (111 in total) were analysed for benthic foraminiferal content. Each sample ( $10 \mathrm{~g}$ dry weight) was treated with $\mathrm{H}_{2} \mathrm{O}_{2}$ to remove the organic matter, and subsequently washed through a $125 \mu \mathrm{m}$ sieve, and dried at $70^{\circ} \mathrm{C}$. A subset containing at least 200 benthic foraminifera for each sample was obtained using an Otto microsplitter. The microfauna have been identified under Leica APO S8 stereoscope. A scanning electron microscope analysis (SEM Jeol JSM 6360) has been used for taxonomical purposes. The number of specimens/gr of dry sediment and the relative abundances of benthic foraminiferal assemblages were calculated. Shannon-Wiener diversity index $\left(\mathrm{H}^{\prime}\right)$ was calculated using the Past.exe 1.23 software package (Hammer et al., 2001). The use of the ratio between large (L) and small (S) Ammonia tests (A-index), A = $100 \times \mathrm{L} / \mathrm{S}+\mathrm{L}$, is applied as a measure of size for Ammonia specimens that can support paleosalinity conditions (Koukousioura et al., 2012).

Pollen analysis was performed on 52 samples from core P4, even though only in 28 of them the pollen concentration was sufficient to be included in the present study. All samples were spiked with known quantity of Lycopodium spores, chemically treated with $\mathrm{HCl}(37 \%), \mathrm{HF}(40 \%)$, acetolysed and finally sieved over a $10 \mu \mathrm{m}$ sieve, while residues were mounted in silicon oil. Pollen identifications were based on Beug's (2004) key and Reille's (1992-1998) atlas, while for the nonpollen palynomorphs (NPPs) identification van Geel et al. $(1989,2003)$ were used. Pollen preservation was good while total pollen concentration ranges from 2700 to 32 grains/ gram of dry sediment. The samples with concentrations below 150 grains/ gram were considerate barren and excluded from this study. Percentage pollen diagram was constructed based on a pollen sum of regional pollen grains, excluding aquatic and hygrophilous pollen and spores. Riverine input has been calculated based on the sum of the erosion indicating NPPs type 207 and Pseudoschizaea. 
Molluscan analysis was realized on 113 selected samples, washed into $125 \mu \mathrm{m}$ sieve and oven dried at $70^{\circ} \mathrm{C}$. The residue was elaborated under a Leica APO S8 stereoscope. All molluscs and fragments were identified and counted in a semi-quantitative approach.

A total of 128 samples from core $\mathrm{P} 4$ have been used for magnetic susceptibility analysis. All samples were sieved in order to remove all the impurities and packed in cylindrical plastic boxes $(2 \times 2 \times 2 \mathrm{~cm})$. The laboratory measurements of the volume-specific magnetic susceptibility ( $\kappa$, SI units) have been performed using the Bartington MS2B sensor at low frequency $(0.465 \mathrm{kHz})$. Our samples were weighed before the measurements therefore all the results are expressed as mass-specific magnetic susceptibility $\left(\chi, 10-8 \mathrm{~m}^{3} / \mathrm{kg}\right)$. Every sample was measured at least 3 times and the average value considered as the final one for the sample. Two air measurements before and after the sample's measurement have been performed in all samples.

\section{Results and Discussion}

The results of the present study enable us to analyze in detail the paleoenvironmental units described by Goiran et al. (2011), in the Piraeus coastal plain. Our combined multiproxy analysis resulted to the subdivision of Unit A (lagoonal environment with mesohaline-oligohaline conditions; 8700$7800 \mathrm{cal}$ BP) of Goiran et al. (2011), into two subunits (Unit Aa and Unit Ab; Figs. 2-4). In particular, in between 17-12 m core depth (Unit Aa), benthic foraminiferal analysis revealed the dominance of Ammonia tepida (>50\%, sometimes up to almost $100 \%$ of the assemblage; Figure 2), together with increased presence of Haynesina germanica (reaching occasionally 60\%; Figure 2). A. tepida is reflecting a wide range of salinity and temperature in near-shore environments; shallow marine, lagoonal and deltaic zones (Jorissen, 1988; Almoghi-Labin et al., 1992; Melis and Violanti, 2006; Frontalini et al., 2009). H. germanica is a species tolerant to restricted conditions (Alve and Murray, 1994; Debenay and Guillou, 2002). This assemblage is featuring mesohaline to oligohaline biofacies in modern closed lagoons of the Aegean area (e.g., Koukousioura et al., 2012; Dimiza et al., 2015). Molluscan assemblages consist mainly of Cerastoderma glaucum (small sized and juvenile forms), Abra spp. and few Hydrobiidae, revealing a typical lagoonal environment (Nicolaidou et al., 1988; Kevrekidis et al., 1996).Similar assemblages feature meso-ologohaline conditions in several Aegean coastal plains (e.g., Triantaphyllou et al., 2003; Evelpidou et al., 2010; Goiran et al., 2011; Syrides, 2008) and define inner lagoon environment (e.g., Carboni et al., 2010; Koukousioura et al., 2012). The interval from 12 to $11 \mathrm{~m}$ core depth (Unit $\mathrm{Ab}$ ) is featured by the high abundance of A. tepida (generally higher than 70\%), accompanied by the presence of Elphidium gunteri and Aubignyna perlucida (up to $20 \%$ ), a typical species of estuarine and shallow marine environments (e.g., Carboni et al., 2010; Evelpidou et al., 2010). Overall similar foraminiferal assemblages have been characterized as open lagoon environments (e.g., Carboni et al., 2010; Koukousioura et al., 2012). In agreement, mollusc fauna presents similar species with Unit Aa, but considerably richer in abundance, representing a lagoonal environment possibly due to a better communication with the sea. Within Unit A, the occurrence of diverse dinoflagellate cysts and foraminifera linnings (Figure 3 ) is the palynological evidence of the marine influence on the deposits (Kouli et al., 2009). In addition, Pseudoschizaea and type 207 are indicators of soil erosion and increased riverine runoff (Figure 3), which together with the high values of magnetic susceptibility (mean $\sim 40 \times 10^{-8} \mathrm{~m}^{3} / \mathrm{kg}$ ) between $12 \mathrm{~m}$ depth and the bottom of the core, imply increased fresh water input in the depositional environment, thus supporting the closed lagoon paleoenvironmental conditions (Ghilardi et al., 2008; Liu et al., 2012). The lower values of magnetic susceptibility within Unit Ab (12-9.5 m core depth) in respect to Unit Aa, point to higher marine influence associated with open lagoon paleoenvironmental conditions. Despite the generally low pollen concentrations of the deposits, which resulted in a fragmented record, spectra of $\mathrm{P} 4$ denote the occurrence of an open mosaic plant landscape with a big diversity of herb taxa (Figure 3 ). 


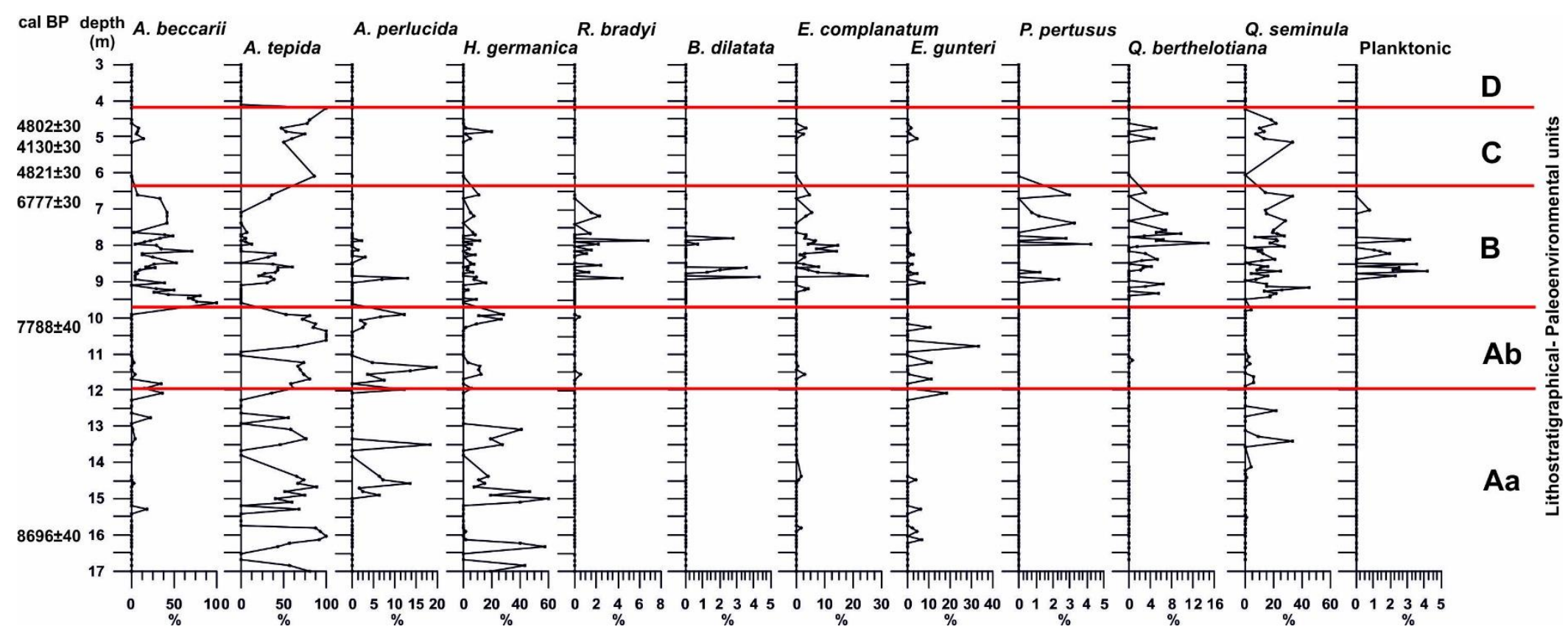

Figure 2 - Foraminiferal relative abundances of borehole P4. 


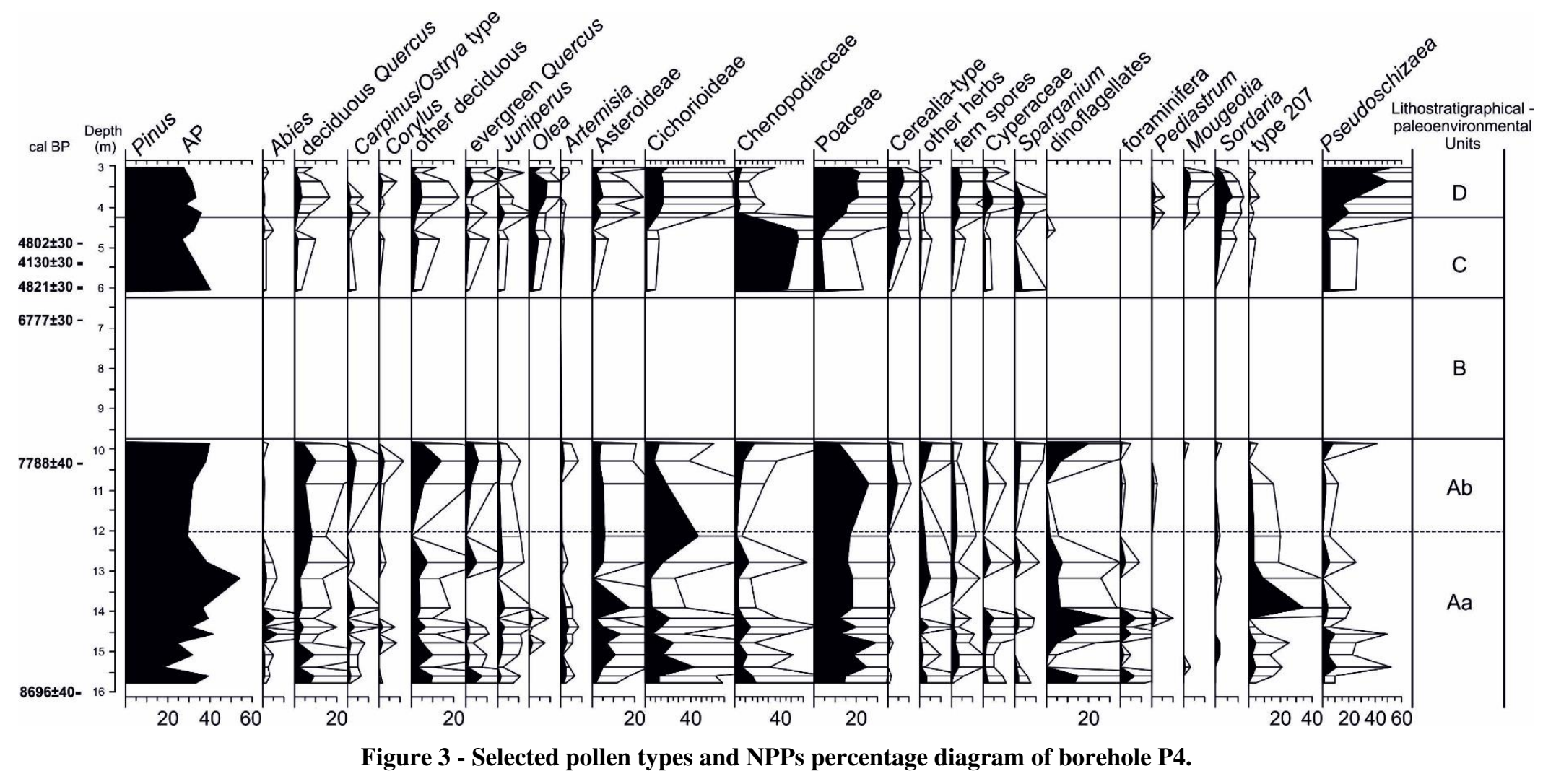




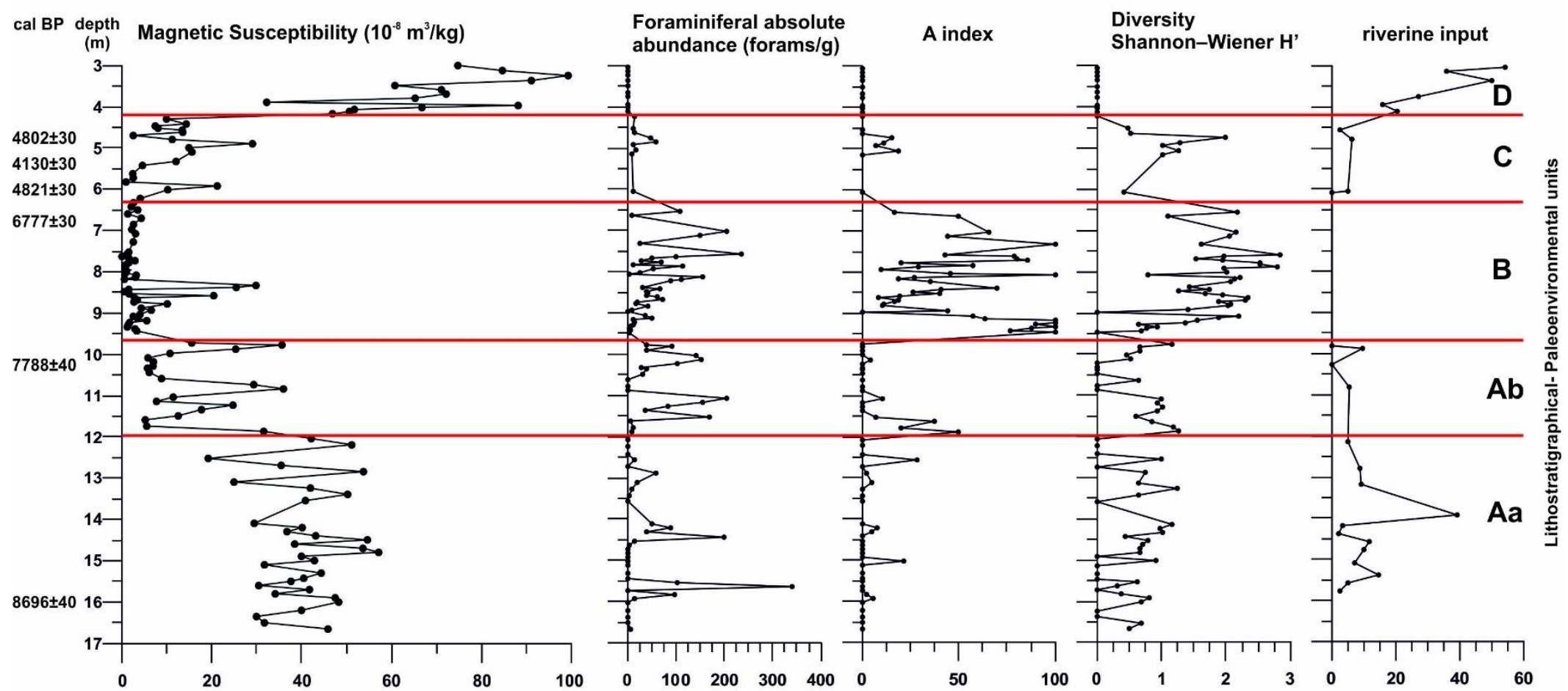

Figure 4 - Magnetic susceptibility, benthic foraminiferal indices and palynomorph-based riverine input estimations of borehole P4. 
Abies shows a profound short-lived peak that coincides with an increase in Artemisia abundances during Unit Aa in-between 15 and $14 \mathrm{~m}$ depth that may be related to a climatic deterioration event during the lower Holocene. Arboreal vegetation (AP), being in general $\sim 30 \%$ of the pollen content, with Pinus being the most common tree taxa, followed by deciduous Quercus, exhibits significantly increased abundances during the middle part of Unit A, in-between 14 and $13 \mathrm{~m}$. Throughout Unit A that corresponds to the Prokeramic to Early Neolithic period, there are no clear indications about human impact on vegetation. Nevertheless the increase of Cerealia-type towards the upper part of the Unit may be the signal of first farming communities in the area.

Benthic foraminiferal assemblages of Unit B (9.5-6.5 m core depth) consist mainly of marine foraminiferal species (e.g., Rosalina bradyi, Bolivina dilatata, Peneroplis pertusus, Elphidium complanatum; Figure 2), increased foraminiferal diversity and high values of A-index (Figure 4). In addition, miliolids (Quinqueloculina berthelotiana, Q. seminula) featuring the infralittoral and upper circalittoral zones (e.g., Sgarrella and Moncharmont Zei, 1993), consist an important fraction of the assemblage together with specimens of planktonic foraminiferal species (Figure 2). However, the presence of euryhaline species such as $H$. depressula, A. tepida suggests a shallow marine palaeoenvironment which also exhibits lagoonal features. Mollusc fauna, represented mainly of Cerithiidae, Bittium sp., Alvania/Rissoa spp. and Tricolia sp. indicates a shallow marine environment (Syrides, 2008), but the intense presence of C. glaucum suggests lagoonal features, confirming the foraminiferal findings. In this period Piraeus was an island in the center of a wide shallow marine bay (Goiran et al., 2011). Magnetic susceptibility values within Unit B are low; especially in the layer from 5.5 to $8.5 \mathrm{~m}$ the lower values of the core $\left(\sim 1 \times 10-8 \mathrm{~m}^{3} / \mathrm{kg}\right)$ are observed, indicating the presence of marine deposits, in accordance with the foraminiferal proxies.

The microfaunal content of Unit C (6.5-4 m core depth) reveals the relative increase of A. tepida and $H$. depressula, along with $Q$. seminula (Figure 2), while molluscan fauna consists of C. glaucum, Abra spp. and numerous Hydrobiidae, suggesting closed lagoon paleoenvironmental conditions, which are supported by the relatively increased magnetic susceptibility values (Figure 4). According to Goiran et al., (2011), a wide lagoon became established in this period that was separated from the sea by beach barriers. This oligohaline closed lagoon, featured in pollen diagrams by expansion of the Chenopodiaceae halophytes (Figure 3), was used for grazing, as indicated by the coprophilous fungal remains of Sordaria and parasites. Asteraceae, Poaceae and Chenopodiaceae are the most common non arboreal taxa, with the latter being the dominant feature of Unit $\mathrm{C}$. The human presence is inevitably detected since Unit C (Early Bronze Age) by the increase of cultivars like Cerealiatype and Olea.

Within Unit D (the upper 4m of the core P4; younger than $2800 \mathrm{yr}$ cal BP, Goiran et al., 2011), the microfauna is characterized by the slight presence of Ammonia and Haynesina and molluscs are totally absent, indicating a marshy oligohaline palaeoenvironment. Magnetic susceptibility shows the higher values of the whole core reaching the maximum of $100 \times 10^{-8} \mathrm{~m}^{3} / \mathrm{kg}$, thus implying the intense impact of fresh water input (Ghilardi et al., 2008). This is also supported by the maximum values of the palynomorph based riverine input estimation (Figure 4). Furthermore the occurrence of numerous fresh water algae of Pediastrum and Mougeotia (Figure 3) is indicative of the fresh water depositional environment within Unit D. Both cultivation and pastoral activities appear intensified during Unit D (Geometric-Classical times). Especially Olea seems to have become a significant cultivar in the area during the Antiquity.

\section{Conclusions}

Our multiproxy interpretation of Piraeus coastal plain paleoenvironmental evolution during the last 8700 cal BP, suggests a very good correlation of benthic foraminiferal results with the palynological and mollusc analysis and magnetic susceptibility data. Thus, the combination of all three methods and resulted indices has the potential to get established as a very promising paleoenvironmental tool box. 


\section{Acknowledgments}

We gratefully acknowledge funding of the research project by the Centre National de la Recherche Scientifique (CNRS).

\section{References}

Almogi-Labin, A., Perelis-Grossovicz, L. and Raab, M., 1992. Living Ammonia from a hypersaline inland pool, Dead Sea area, Israel, Journal of Foraminiferal Research, 22, 257-266.

Alve, E. and Murray, J.W., 1994. Ecology and taphonomy of benthic foraminifera in a temperate mesotidal inlet, Journal of Foraminiferal Research, 24(1), 18-27.

Bellini, C., Mariotti-Lippi, M. and Montanari, C., 2009. The Holocene landscape history of the NW Italian coasts, Holocene, 19, 1161-1172.

Beug, H.-J., 2004. Leitfaden der Pollenbestimmung für Mitteleuropa und angrenzende Gebiete, 17 Verlag Dr. Friedrich Pfeil, München, Germany.

Carboni, G.M., Bergamin, L., Di Bella, L., Esu, D., Pisegna Cerone, E., Antonioli, F. and Verrubbi, V., 2010. Palaeoenvironmental reconstruction of late Quaternary foraminifera and mollusks from the ENEA borehole (Versilian plain, Tuscany, Italy), Quaternary Research, 74, 265-276.

Dearing, J.A., 2000. Magnetic susceptibility. In: Walden, J., Oldfield, F. and Smith, J., eds, Environmental Magnetism: A Practical Guide, Technical Guide No.6. Quaternary Research Association, London.

Debenay, J.-P. and Guillou, J.-J., 2002. Ecological transitions indicated by foraminiferal assemblages in paralic environments, Estuaries, 25(6A), 1107-1120.

Dimiza, M.D., Koukousioura, O., Triantaphyllou, M.V. and Dermitzakis, M.D., 2015. Live and dead benthic foraminiferal assemblages from coastal environments of the Aegean Sea (Greece): Distribution and diversity, Revue de Micropaléontologie, doi: org/10.1016/j.revmic.2015.10.002.

Evelpidou, N., Pavlopoulos, K., Vassilopoulos, A., Triantaphyllou, M., Vouvalidis, K. and Syrides, G., 2010. Sea level changes in Upper Holocene and palaeogeographical reconstruction, Geodinamica Acta, 23(5-6), 233-240.

Frontalini, F. and Coccioni, R., 2008. Benthic foraminifera for heavy metal pollution monitoring: a case study from the central Adriatic Sea coast of Italy, Estuarine Costal and Shelf Science, 76(2), 404-417.

Frontalini, F., Buosi, C., Da Pelo, S., Coccioni, R., Cherchi, A. and Bucci, C., 2009. Benthic foraminifera as bio-indicators of trace element pollution in the heavily contaminated Santa Gilla lagoon (Cagliari, Italy), Marine Pollution Bulletin, 58, 858-877.

Ghilardi, M., Kunesch, S., Styllas, M. and Fouache, E., 2008. Reconstruction of Mid-Holocene sedimentary environments in the central part of the Thessaloniki Plain (Greece), based on microfaunal identification, magnetic susceptibility and grain-size analyses, Geomorphology, 97, 617-630.

Goiran, J.-P., Pavlopoulos, K.P., Fouache, E., Triantaphyllou, M. and Etienne, R., 2011. Piraeus, the ancient island of Athens: Evidence from Holocene sediments and historical archives, Geology, 39(6), 531-534.

Hammer, O., Harper, D.A.T. and Ryan, P.D., 2001. Past Paleontological statistics software. Package for education and data analysis. Paleontologia Electronica.

Jorissen, F.J., 1988. Benthic foraminifera from the Adriatic Sea: principles of phenotypic variation, Utrecht Micropaleontological Bulletin, 37, 1-174.

Kevrekidis, T., Gouvis, N. and Koukouras, A., 1996.Bionomy of Macrobenthic Molluscs in Evros Delta (North Aegean Sea), Int. Revue ges. Hydrobiol., 81(3), 455-468.

Koukousioura, O., Dimiza, M.D., Triantaphyllou, M.V. and Hallock P., 2011. Living benthic foraminifera as an environmental proxy in coastal ecosystems: A case study from the Aegean Sea (Greece, NE. Mediterranean), Journal of Marine Systems, 88(4), 489-501.

Koukousioura, O., Triantaphyllou, M.V., Dimiza, M.D., Pavlopoulos, K., Syrides, G. and Vouvalidis, K., 2012. Benthic foraminiferal evidence and paleoenvironmental evolution of Holocene coastal plains in the Aegean Sea (Greece), Quaternary International, 261, 105-117. 
Kouli, K., 2012. Vegetation development and human activities in Attiki (SE Greece) during the last 5000 years, Veget. Hist. Archaeobot., 21, 267-278.

Kouli, K., Triantaphyllou, M., Pavlopoulos, K., Tsourou, T., Karkanas, P. and Dermitzakis, M.D., 2009. Palynological investigation of the Holocene palaeoenvironmental changes in the coastal plain of Marathon (Attica, Greece), Geobios, 42, 43-51.

Liu, Q.S., Roberts, A.P., Larrasoaña, J.C., Banerjee, S.K., Guyodo, Y., Tauxe, L. and Old-field, F., 2012. Environmental magnetism: principles and applications, Reviews of Geophysics, 50, RG4002.

Melis, R. and Violanti, D., 2006. Foraminiferal biodiversity and Holocene evolution of the Phetchaburi coastal area (Thailand Gulf), Marine Micropaleontology, 61, 94-115.

Murray, J.W., 2007. Ecology and Applications of Benthic Foraminifera, Cambridge University Press, 426 pp.

Nicolaidou, A., Bourgoutzani, F., Zenetos, A., Guelorget, O. and Perthuisot, J.P., 1988. Distribution of Molluscs and Polychaetes in coastal lagoons in Greece, Estuar. Coast. Shelf S., 26, 337-350.

Oldfield, F. and Yu, L., 1994.The influence of particle size variations on the magnetic properties of sediments from the north-eastern Irish Sea, Sedimentology, 41, 1093-1108.

Pavlopoulos, K., Theodorakopoulou, K., Bassiakos, Y., Hayden, B., Tsourou, T., Triantaphyllou, M., Kouli, K. and Vandarakis, D., 2007.Paleoenvironmental evolution of Istron (N.E. Crete), during the last 6000 years: depositional environment, climate and sea level changes, Geodinamica Acta, 20(4), 219-229.

Pavlopoulos, K., Triantaphyllou, M., Karkanas, P., Kouli, K., Syrides, G., Vouvalidis, K., Palyvos, N. and Tsourou, T., 2010. Paleoenvironmental evolution and prehistoric human environment, in the embayment of Palamari (Skyros Island, Greece) during Middle-Late Holocene, Quaternary International, 216, 41-53.

Reille, M., 1992-1998. Pollen et spores d' Europe et d' Afrique du Nord. Laboratoire de Botanique Historique et Palynologie, Marseille.

Sadori, L., Giardini, M., Giraudi, C. and Mazzini, I., 2010.The plant landscape of the imperial harbour of Rome, J. Archaeol. Sci. 37, 3294-3305.

Scott, D.S. and Medioli, F.S., 1980. Quantitative studies of marsh foraminiferal distributions in Nova Scotia and comparison with those in other parts of the world: implications for sea level studies, $A$ Special Publication of the Cushman Foundation for Foraminiferal Research, 17, 58.

Sgarrella, F. and Moncharmont Zei, M., 1993. Benthic foraminifera of the Gulf of Naples (Italy): systematics and autoecology, Bollettino della Società Paleontologica Italiana, 32, 145-264.

Syrides, G., 2008. Marine mollusk fauna and Holocene stratigraphy of the marsh of Agia Paraskevi, (Lamia, Fthiotida) Greece, Bulletin of the Geological Society of Greece, XLII/I, 1-14.

Triantaphyllou, M.V., Pavlopoulos, K., Tsourou, Th. and Dermitzakis, M.D., 2003. Brackish marsh benthic microfauna and paleoenvironmental changes during the last 6.000 years on the coastal plain of Marathon (SE Greece), Rivista Italiana Paleontologia et Stratigrafia, 109(3), 539-547.

Triantaphyllou, M.V., Kouli, K., Tsourou, T., Koukousioura, O., Pavlopoulos, K. and Dermitzakis, M.D., 2010. Paleoenvironmental changes since $3000 \mathrm{BC}$ in the coastal marsh of Vravron (Attica, SE Greece), Quaternary International, 216, 14-22.

van Geel, B., Buurman, J., Brinkkemper, O., Schelvis, J., Aptroot, A., van Reenen, G. and Hakbijl, T., 2003. Environmental reconstruction of a Roman period settlement site in Uitgeest (The Netherlands), with a special reference to coprophilous fungi, J. Archeol. Sci., 30, 833-873.

van Geel, B., Coope, G.R. and van der Hammen, T., 1989. Paleoecology and stratigraphy of the Late Glacial type section at Usselo (The Netherlands), Rev. Palaeobot. Palynol., 60, 25-129.

Verosub, K.L. and Roberts, A.P., 1995. Environmental magnetism: past, present, and future, Journal of Geophysysical Research, 100, 2175-2192.

Wang, Y.H., Yu, Z.G., Li, G.X., Oguchi, T., He, H.J. and Shen, H.T., 2009. Discrimination in magnetic properties of different-sized sediments from the Changjiang and Huanghe estuaries of China and its implication for provenance of sediment on the shelf, Mar. Geol., 260, 121-129.

Yang, X.Q., Rodney, G., Zhou, H.Y. and Yang, J., 2008. Magnetic properties of sediments from the Pearl River Delta, South China: paleoenvironmental implications, Science China Earth Sciences, doi: CNKI: SUN:JDXG.0.2008-01-007. 
